\title{
SEDIMENT CONCENTRATION IN MELT WATERS AS AN INDICATOR OF EROSION PROCESSES BENEATH AN ALPINE GLACIER
}

\author{
By David N. Collins \\ (Department of Geography, University of Manchester, Manchester M ${ }_{1} 3$ PL, England)
}

\begin{abstract}
Suspended-sediment concentrations in melt waters from the Gornera, Gornergletscher, Switzerland, were determined at hourly intervals for periods during the ablation seasons of 1974 and 1975 . Rapid erratic fluctuations of suspended-sediment concentration produced peaks which occurred both before and after highest daily flows. Clockwise daily hysteresis rating loops between sediment concentration and discharge included many involutions. Suspended-sediment-concentration-discharge rating curves were different for rising and falling limbs of individual diurnal hydrographs and varied from day to day. Closeinterval measurements of sediment concentration and discharge records allow interpretation of the nature of ice-water-sediment interactions at the bed of an Alpine glacier. At Gornergletscher, subglacial sediment is delivered to melt waters flowing in the smaller basal conduits, which often change course suddenly, entraining unworked sediment stored at the bed. During diurnal discharge maxima, sediment concentration in the Gornera is reduced because the rate of increase of water volume outstrips the rate of supply of sediment. The drainage of the ice-dammed lake Gornersee, producing exceptionally high flows, extended the drainage network over large areas of the glacier bed, and evacuated much sediment.
\end{abstract}

RÉsumé. Concentration de sédiments dans les eaux de fusion comme indicateurs de l'érosion sous un glacier alpin. On a déterminé les concentrations en matériaux en suspension dans les eaux de fusion provenant du Gornera sur le Gornergletscher, en Suisse, à des intervalles horaires pour des périodes des saisons d'ablation de 1974 et 1975. Des fluctuations brusques et capricieuses de la teneur en matériaux en suspension ont produit des pointes soit avant soit après les crues journalières. Des phénomènes d'hystérésis au cours de la journée provoquant des chevauchements entre la concentration en sédiments et les débits ont produit de nombreux cas de figure. Les courbes de teneur en matériaux en suspension selon les débits sont différentes pour les branches ascendantes et descendantes des hydrogrammes quotidiens individuels et variables d'un jour à l'autre. Les mesures fréquentes de concentration en sédiments et les enregistrements de débits permettent une interprétation quant à la nature des interactions glace-eau-sédiments le long du lit d'un glacier alpin. Au Gornergletscher, les matériaux sous-glaciaires sont livrés aux eaux de fusion coulant dans les plus petits chenaux du fond, qui changent souvent brusquement de cours, entraînant des matériaux non travaillés stockés sur le lit. Pendant la période de débit journalier maximum, la teneur en matière solide du Gornera est réduite parce que la vitesse d'accroissement du volume de l'eau excède la vitesse de fourniture du matériel. La vidange du lac derrière le barrage de glace du Gornersee, produisant des eaux exceptionnellement hautes étend le réseau de drainage à de vastes surfaces du lit glaciaire et évacuent beaucoup de sédiments.

Zusammenfassung. Sediment-Konzentration im Schmelzwasser als Indikator von Erosionsvorgängen unter einem Alpengletscher. In Schmelzwassern der Gornera, Gornergletscher, Schweiz, wurde für Perioden während der Ablationszeit von 1974 und 1975 stündlich die Konzentration suspendierter Sedimente bestimmt. Schnelle, regellose Schwankungen der Sediment-Konzentration führten zu Spitzen sowohl vor wie nach den täglichen Höchstständen. Tägliche Hystereseschleifen im Uhrzeigersinn zwischen Sediment-Konzentration und Abfluss zeigten viele Involutionen. Die Kurven der Abflussraten und der Konzentration von suspendierten Sedimenten waren unterschiedlich für die steigenden und fallenden Äste einzelner Tageswasserstandsgänge und änderten sich von Tag zu Tag. Kurzfristige Messungen der Sediment-Konzentration und Abflussaufzeichnungen gestatten eine Interpretation der Wechselwirkungen zwischen Eis, Wasser und Sediment am Grunde eines Alpengletschers. Am Gornergletscher gelangt suglaziales Sediment in Schmelzwässer, die in den kleineren Wasserführungen am Untergrund fliessen, oft ihren Lauf unvermittelt ändern und dabei unbearbeitetes Sediment vom Untergrund aufnehmen. Während der täglichen Abflussmaxima ist die Sediment-Konzentration in der Gornera reduziert, weil die Zunahme der Wassermenge den Sedimentennachschub überwiegt. Der Abfluss des vom Eis abgedämmten Gornersees verursachte ungewöhnlich hohe Wasserstände, erweiterte das Abflusssystem über grosse Gebiete des Gletscherbetts und führte viel
Sediment ab.

\section{INTRODUCTION}

While direct observations in natural cavities at glacier beds and remote sensing of basal conditions through bore holes have provided considerable insight into the nature of erosional processes, the processes by which sedimentary materials are transferred from sites of origin at the ice-bedrock interface to melt-water streams beneath Alpine glaciers remain largely unknown. The interaction of basal melt streams with the products of glacial erosion is of interest, since measurements of the quantities of suspended sediments and solutes evacuated 
from partly glacier-covered catchments provide means of estimating gross rates of denudational lowering by glacial erosion (Østrem, [ $\left.{ }^{c} 1975\right]$ ) and chemical weathering (Reynolds and Johnson, 1972), and of identifying the relative significance of various subglacial processes (Vivian and Zumstein, 1973). Observation of the quality of water draining from glacier snouts permits investigation of the nature of erosional processes integrated over large areas of glacier bed, effectively sampled by flowing melt waters which acquire their characteristics during passage beneath the glacier.

Complex relationships between suspended-sediment concentration and discharge, with large variations in sediment content both dependent on discharge fluctuations and occurring as random events (Østrem, [ $\left.{ }^{c}{ }_{1} 975\right]$ ) suggest that close-interval sampling of melt-water quality characteristics should allow interpretation of subglacial interactions of water flow and erosional sediment supply. Using measurements of sediment concentration and discharge every few hours throughout $24 \mathrm{~h}$ periods, Liestøl (1967) demonstrated that melt streams beneath Storbreen, Norway, frequently changed course.

The present investigation was designed to use hourly observations of suspended-sediment concentration to provide detailed information concerning the interaction of melt waters in basal conduits with subglacial sources of sedimentary material and to assess the relationship between sediment concentration and discharge with respect to sediment-rating curves. The study was carried out on the Gornera, the only melt-water stream draining from Gornergletscher, Canton Wallis, Switzerland, which with tributary glaciers covers $83.7 \%$ of a catchment of $82 \mathrm{~km}^{2}$. The bedrock topography beneath the trunk Gornergletscher is known in detail from seismic investigations and bore holes, and a thick basal morainic layer, up to $50 \mathrm{~m}$ thick at the centre of the glacier has been proved by drilling and inferred from soundings (Bezinge and others, 1973). The Gornera is gauged $1 \mathrm{~km}$ from the glacier snout.

\section{SAMPLE COLLEGTION AND PROCESSING}

In 1974, samples of melt water and sediments were collected at hourly intervals for selected periods at a site $50 \mathrm{~m}$ from the glacier portal in order to minimize effects of channel scour and fill, and about $3 \mathrm{~m}$ from the channel bank, with a depth-integrating DH-48 sediment sampler. In July and August 1975, a sample was collected every hour throughout each $24 \mathrm{~h}$ period using a North Hants Engineering Company automatic liquid sampler. A modified sampling nozzle, consisting of 24 I0.0 mm I.D. polyethylene tubes bound together with wire, was fixed in the stream so as to remain below the water level at the lowest stages of flow, orientated at an angle of $45^{\circ}$ from the water surface up-stream. The nozzle varied in depth at differing stages of flow, from 0.1 to $0.7 \mathrm{~m}$ beneath the average level of the turbulent water surface, and remained $\mathrm{I} \mathrm{m}$ from the channel bank at a site $250 \mathrm{~m}$ from the glacier snout. Using a vacuum of $460-480 \mathrm{~mm} \mathrm{Hg}, 0.7-0.91$ samples were usually drawn up. Each sample bottle was connected by an individual tube of length $3 \mathrm{~m}$ to the nozzle, so that samples received no contamination from those collected in previous hours. Occasionally, at times of high sediment concentration, tubes of the North Hants sampler became blocked by sediment particles larger than I $\mathrm{mm}$ diameter becoming sucked into the end of the hose, preventing water and sediment from reaching the sample bottle. Samples of volume less than $0.7 \mathrm{l}$ were discarded. After every $24 \mathrm{~h}$ sample cycle, the clear polyethylene tubes were examined, and a sample rejected if particles had remained in the tube. Over $80 \%$ of the possible number of samples were collected successfully.

In both 1974 and 1975, volumes of samples were determined in measuring cylinders. Sediment samples were separated from waters in the field by filtration through individually pre-weighed Whatman 542 hardened cellulose filter papers, under pressure from a hand pump. Samples were returned to the laboratory in sealed bags, oven dried at $105^{\circ} \mathrm{C}$ for $8 \mathrm{~h}$, and the quantity of sediment determined gravimetrically. No organic material was present in the 
samples. Some fine particles $(<3.0 \mu \mathrm{m})$ less than the initial pore size, may have passed through the filter papers. The sediment processing leads to errors of $\pm 20 \mathrm{mg}$, and the measurement of volume $\pm 5 \mathrm{ml}$, giving overall error of about $5 \%$.

\section{REsults AND ANALYSIS}

\section{Suspended-sediment concentration}

Temporal variations of suspended-sediment concentration during a period of sustained ablation from 28 July to 3 August 1975, shown in Figure I, ranged between 94 and I 919 $\mathrm{mg} \mathrm{l}^{-1}$, which both occurred on 3 August, though on the other days concentrations ranged only from 100 to $810 \mathrm{mg} \mathrm{l}^{-1}$. Daily sediment-concentration maxima occurred within several hours of daily peak discharge, on some days preceding the time of discharge peak and others following, although 3 August presented an anomalous occasion. Every day, the peak discharges were accompanied by minimum concentrations of suspended sediment. Precipitation was of low intensity and infrequent throughout the period. Extremely high sediment concentration during the early hours of 3 August appears to have been related to an unusually high minimum discharge. While this discharge remained steady, sediment concentration fell by $95 \%$. Irregularity of sediment concentration suggests rapid injection of sediment impulses into subglacial streams followed by exhaustion, recurring independently of rhythmic variations of diurnal discharge.

Low temperatures and continuous cloud cover reduced absolute discharge of the Gornera and the daily amplitude of the diurnal rhythm of flow from I I to 13 August (Fig. 2). Suspended-sediment concentration varied in phase with discharge on I I August but lower flow on the following day produced no sediment peak and concentration remained below $3^{60} \mathrm{mg}^{1^{-1}}$.

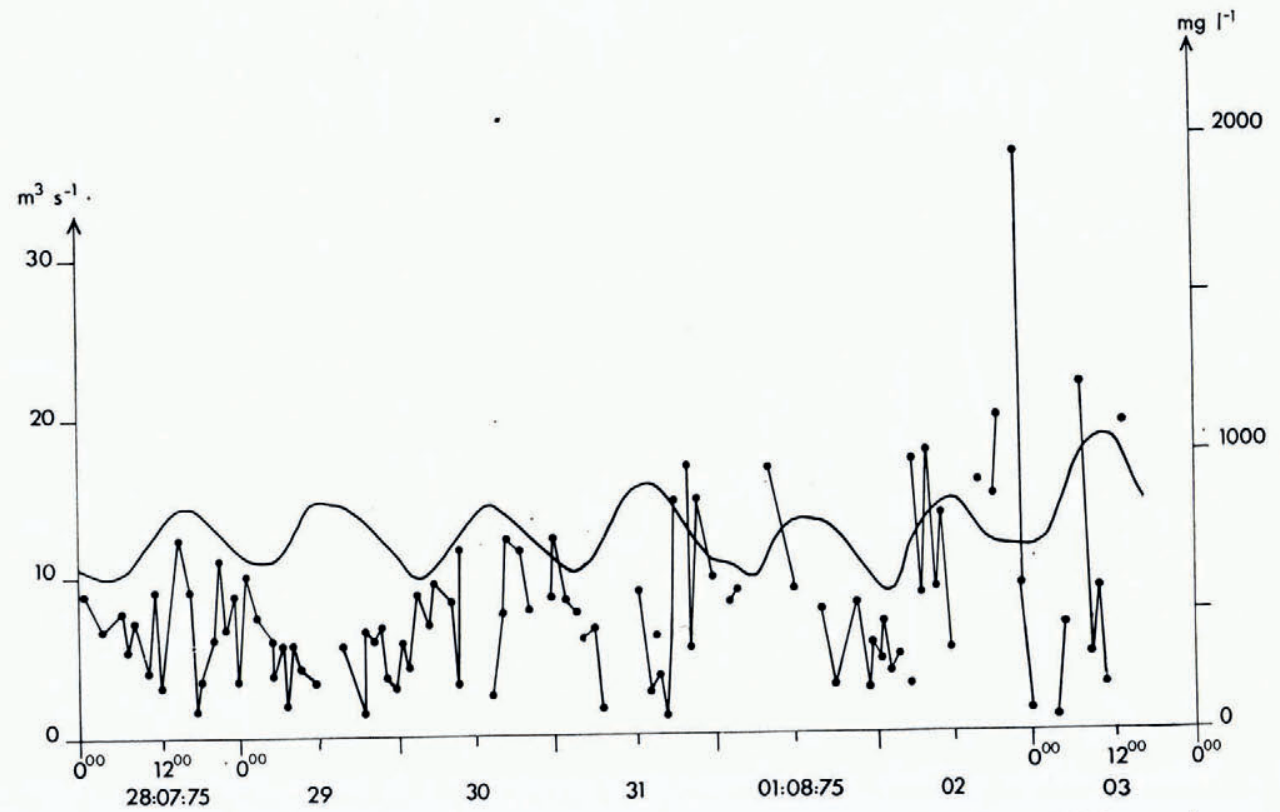

Fig. 1. Temporal variations of discharge and suspended-sediment concentration in the Gornera from 28 July to 3 August 1975. Instantaneous sediment-concentration determinations were obtained for samples collected by a North Hants Engineering Instantaneous sediment-concentration determinations were obtained for samples collected by a conples have been connected to provide a curve of suspended-sediment concentration. Sediment-concentration peaks occurred both before and after times of peak daily discharge, which were associated with minimum daily sediment concentrations during this period of sustained ablation. An anomalously high overnight discharge on 2-3 August was associated with high suspended-sediment concentration. 
Rainfall during this period showed no relationship to peaks, suggesting that subglacial sources contribute much greater quantities of sediment than marginal ice-free morainic slopes. Restoration of favourable ablation conditions after 14 August increased both discharge and sediment concentration, but concentration occurred out of phase with flow, lowest concentrations being timed simultaneously with diurnal discharge maxima. The highest suspendedsediment concentration in this period (2 $234 \mathrm{mg} \mathrm{l}^{-1}$ ) occurred overnight $\mathrm{I}_{6-1} 7$ August, following an unusually shaped hydrograph peak which may have resulted from temporary restriction of subglacial conduit flow. A further high sediment-concentration peak was

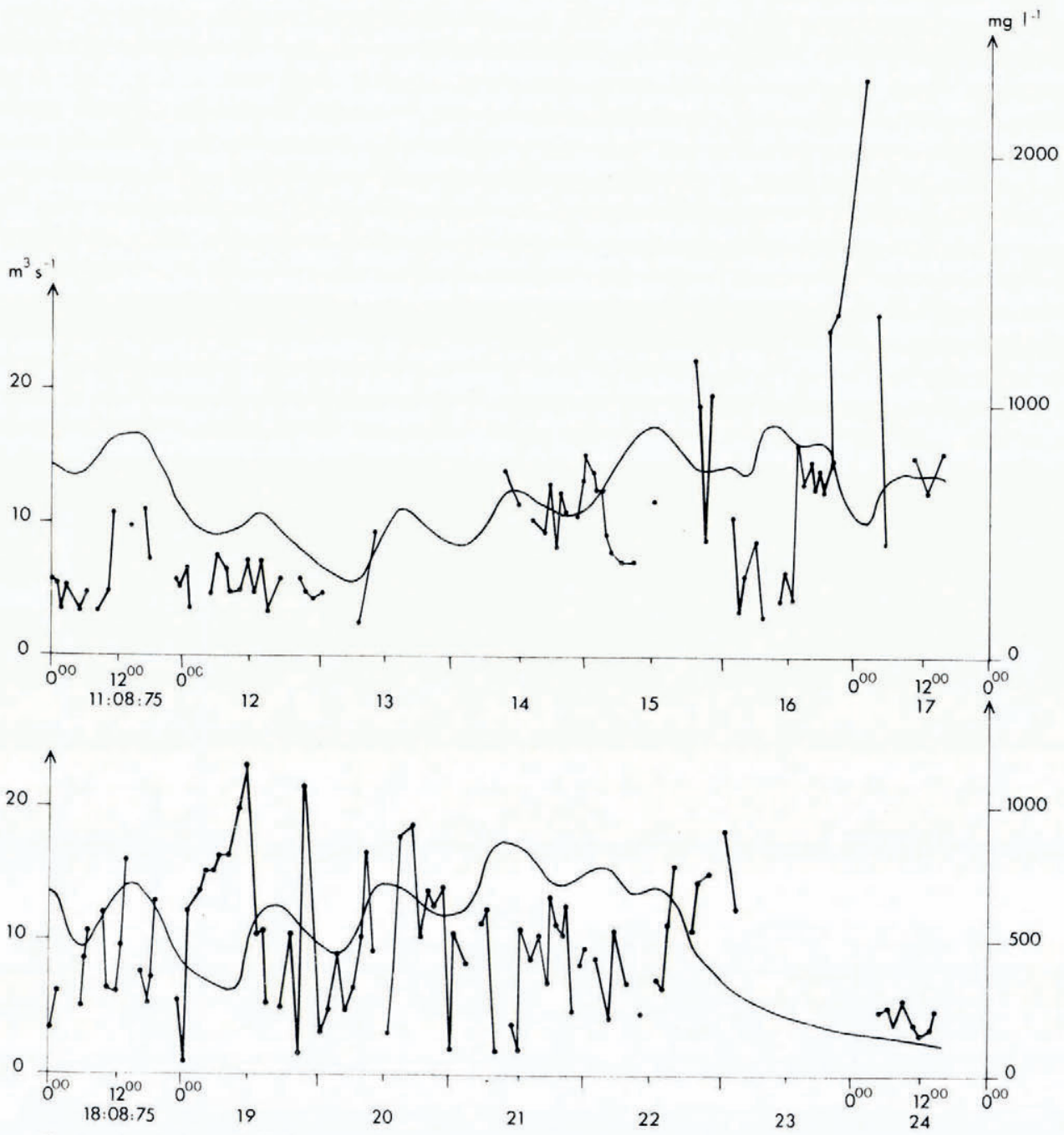

Fig. 2. Temporal variations of discharge and suspended-sediment concentration in the Gornera from II to 24 August 1975 . Instantaneous suspended sediment samples were collected by a North Hants Engineering Company automatic liquid sampler. Discharge and sediment concentration declined from 11 to ${ }_{13}$ August during an overcast cool period. Restored ablation produced a slow rise in peak and minimum discharges. High sediment concentration overnight on $16-17$ August followed an unusual peak flow, which probably resulted from blocking of subglacial conduits. Release of subglacial water subsequently provided large quantities of sediment to the Gornera. High sediment concentration was associated with low flow on I9 August. Snow-fall from 22 August caused reduced flow in the Gornera, and consequently lowered turbulence and velocities resulted in decreased sediment concentrations. 
produced during the lowest daily flow on 19 August. Subsequently, daily sediment concentrations were in the range $100-1$ ooo $\mathrm{mg} \mathrm{l}^{-1}$; daily minima were followed in 2 or $3 \mathrm{~h}$ by daily maximum values of sediment concentration, $3^{-6 \mathrm{~h}}$ after the times of maximum water discharge. Snow-fall from 22 August caused reduced inputs of melt water to the Gornergletscher, and recession flow of the Gornera was associated with first increased, followed by low (I I 4-27 I $\mathrm{mg} \mathrm{l}^{-1}$ ), sediment concentrations. Flow in subglacial streams decreased with declining discharge, either causing temporary deposition of sediment into channel storage or leaving the channel-margin ice-sediment interfaces out of contact with water.

In 1974, consecutive hourly observations were undertaken for such periods as possible before, during, and after the draining of the Gornersee, an ice-dammed marginal lake which accumulates in the apex of the junction of the trunk Gornergletscher with one of its tributaries, Grenzgletscher, about $6 \mathrm{~km}$ from the glacier portal. Annual catastrophic drainage of the lake under Gornergletscher produces floods in the Gornera for 2-4 d (Bezinge and others, 1973). The usual pattern of sediment-discharge relationships occurred on 26-27 July before the beginning of the drainage (Fig. 3). The first release of water from the lake occurred in the early afternoon of 29 July, when the usual decrease of flow was replaced by the rising limb of the lake-burst hydrograph. Sediment concentration increased from $2900 \mathrm{mg} \mathrm{l}^{-1}$ to $575^{\circ}$ $\mathrm{mg}^{-1}$ in $2 \mathrm{~h}$. On 30 July, sediment concentration was irregular, but never declined beneath $4000 \mathrm{mg} \mathrm{l}^{-1}$, and reached a maximum of $7215 \mathrm{mg} \mathrm{l}^{-1}$. The highest discharge $\left(54 \mathrm{~m}^{3} \mathrm{~s}^{-1}\right)$ during draining resulted from the superimposition of the maximum flow from the lake burst on the usual diurnal maximum flow of the late afternoon on $3^{\mathrm{I}} \mathrm{July}$. Sediment concentration continued to rise to a maximum of ${ }_{1} \mathrm{I} 800 \mathrm{mg} \mathrm{l}^{-1}, 2 \mathrm{~h}$ after peak discharge, and remained relatively high, suggesting continued availability of sediment throughout I August as the normal diurnal component of discharge re-appeared on the falling limb of the lake-burst hydrograph. On 2 August, when sediment concentration showed a direct in-phase relationship with discharge, the sediment peak occurred about $2 \mathrm{~h}$ before peak discharge. By 3 August, although suspended-sediment concentration remained greater than $2000 \mathrm{mg}^{-1}$, the usual dilution effect was associated with maximum discharge, suggesting that easily worked sediment had been flushed from the conduit system.

\section{Suspended-sediment-concentration-discharge relationships}

In order to assess the nature of sediment supply beneath the glacier and the interaction of water flow with sediments at the bed, the relationship between suspended-sediment concentration and discharge was investigated. Suspended-sediment-concentration-discharge relationships of the form $S_{\mathrm{s}}=a Q^{b}$, where $S_{\mathrm{s}}$ is suspended-sediment concentration, $Q$ discharge, and $a$ and $b$ best-fit estimated parameters, were fitted to data collected in 1974, using $r^{2}$ as an index of goodness of fit of the model. The range of best-fit parameters and low degrees of fit indicate that the relationship between sediment concentration and discharge in the Gornera is non-stationary, and varies between rising and falling limbs of diurnal hydrographs (Table I). Better fit of the model applied to relationships between suspended-sediment transport and discharge in glacial melt-water streams (Church, 1972; Østrem, [ $\left.{ }^{\mathrm{c}} \mathrm{I} 975\right]$ ) probably results from the use of the statistically spurious association between discharge and sediment transport (Benson, 1965). Use of the master rating curve to estimate suspended-sediment concentration for periods when samples are not collected would result in considerable inaccuracy. In nonglacial catchments, gross errors in the assessment of sediment load arise from use of sedimentrating curves, especially when hysteresis is present (Walling, 1977).

The effects of hysteresis dynamics in the relationship between sediment concentration and discharge in the Gornera are illustrated by rating loops for 18-19 August 1975, cycling in a clockwise direction and including involutions (Fig. 4). Clockwise hysteresis loops result from greater concentrations of suspended sediments on the rising limb of the diurnal hydrograph 

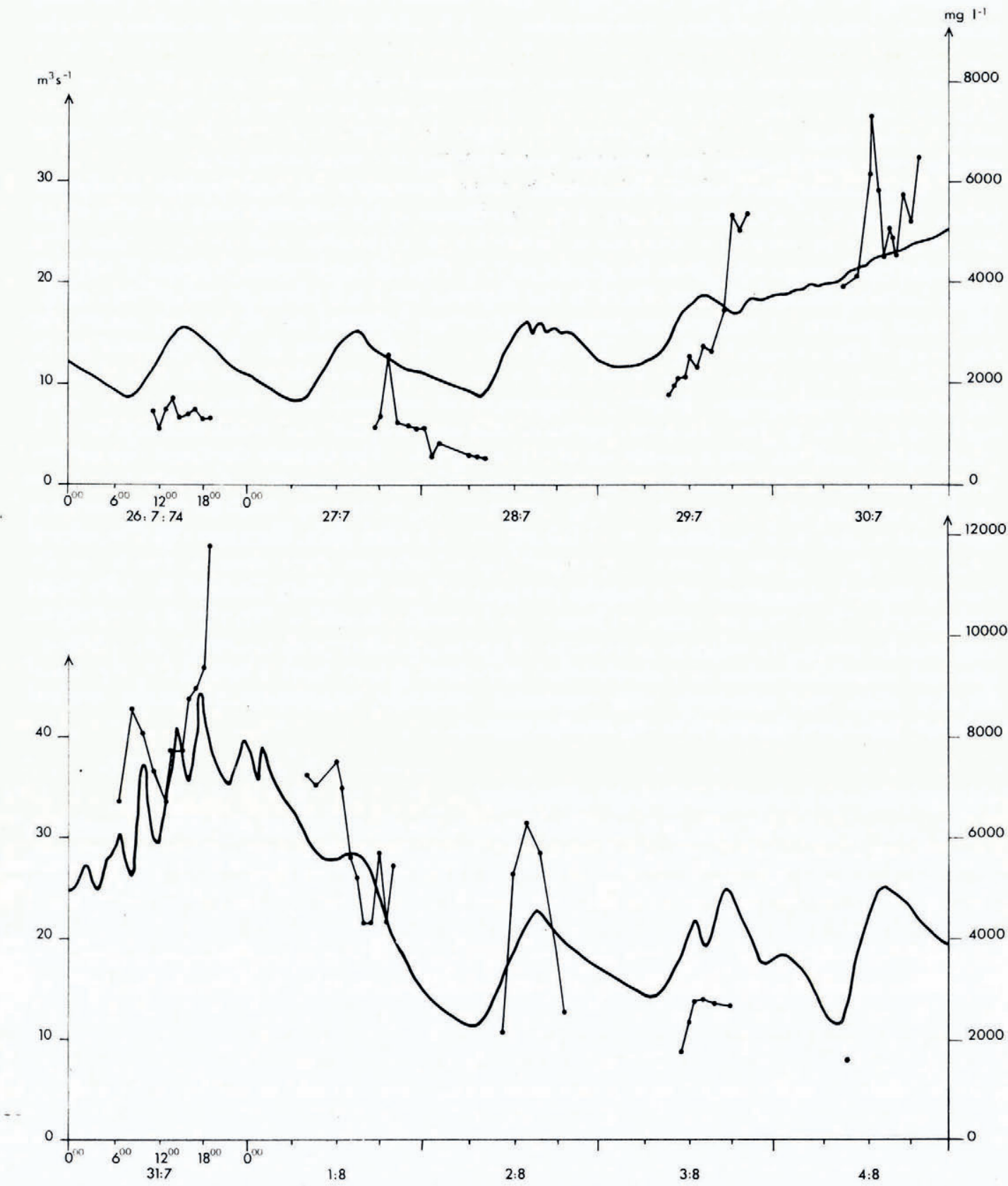

Fig. 3. Temporal variations of discharge and suspended-sediment concentration in the Gornera from 26 July to 4 August 1974 , before, during, and after the drainage of the Gornersee. Water escaped from the lake in the afternoon of 297 July and draining continued until I August. Sediment samples were collected hourly for several periods during the lake burst. No sediment exhaustion was observed during drainage and sediment concentration remained high on 2 August with no reduction at the time of maximum discharge. 
TABle I. PARAmeters of THE MODEL $S_{\mathrm{s}}=a Q^{b}$ FOR SUSPENDED-SEDIMENT-ConcenTRATION-DISCHARGE RELATIONSHIPS IN THE GORNERA, DETERMINED FOR RISING AND FALLING LIMBS OF DAILY HYDROGRAPHS DURING THE I974 ABLATION SEASON

Date

I9 July 1974

21 July 1974

22 July 1974

22 July 1974

26 July 1974

26 July 1974

27 July 1974

I August 1974

3 August r 974

Io August 1974

Io August 1974

I I August 1974

All data

Hydrograph limb
Falling
Rising
Rising
Falling
Rising
Falling
Falling
Falling
Rising
Rising
Falling
Rising
Rising and falling

Suspended sediment-discharge relationship

\begin{tabular}{rcc}
\hline$a$ & $b$ & $r^{2}$ \\
0.10 & 4.65 & 0.64 \\
0.13 & 5.22 & 0.88 \\
3.47 & 2.59 & $0.8 \mathrm{I}$ \\
20.76 & 1.90 & 0.78 \\
739.52 & 0.29 & 0.09 \\
73.11 & 1.08 & 0.79 \\
3.62 & 2.29 & 0.61 \\
37.45 & 1.53 & 0.64 \\
64.20 & 1.19 & 0.61 \\
39.10 & 1.08 & 0.40 \\
186.79 & 0.48 & 0.21 \\
39.81 & 1.09 & 0.72 \\
9.20 & 1.91 & 0.78
\end{tabular}

than at equivalent discharges during the falling stage, resulting from the flushing out of sediment collected at margins and beds of subglacial streams during low flows. A distinct loop occurred each day during periods of sustained ablation, often with figure-of-eight sub-loops and involutions, reflecting irregularity in sediment availability. More regular relationships, in which daily peaks of sediment concentration precede discharge peaks by several hours, have been shown for glacial melt streams in Norway and on Baffin Island (Østrem and others, I967; Østrem, [ ${ }^{\mathrm{c}}$ I975]).

\section{Suspended-sediment transport}

Instantaneous suspended-sediment transport $\left(\mathrm{kg} \mathrm{s}^{-1}\right)$ in the Gornera was derived from discharge $\times$ sampled sediment concentration for those hours for which data were available. Temporal variation in the evacuation of sediment from beneath Gornergletscher was extremely

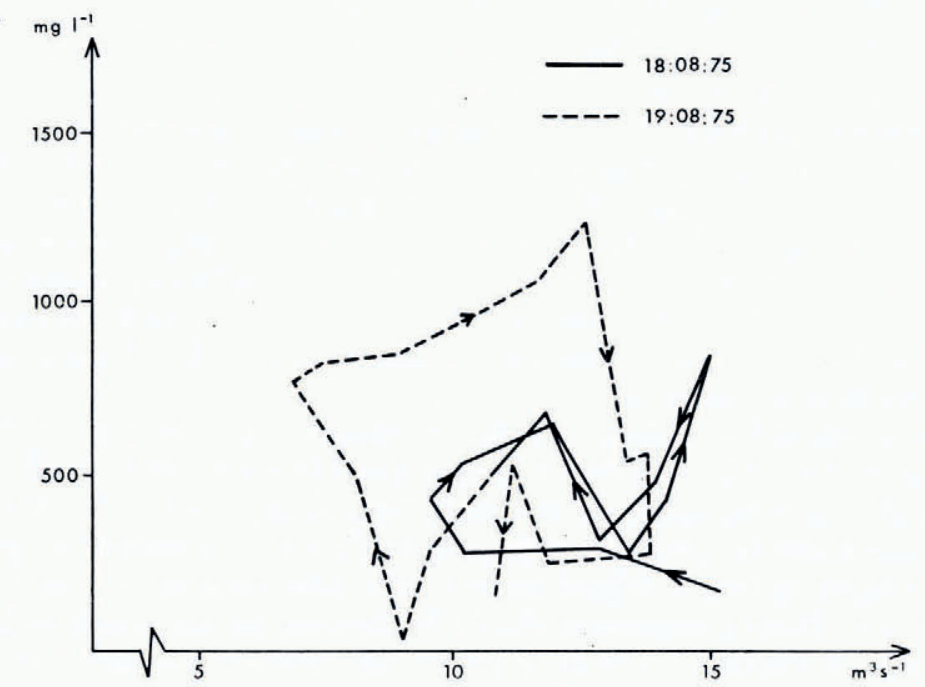

Fig. 4. Hysteresis rating loops for suspended-sediment concentration with discharge in the Gornera for 18 and 19 August 1975 . Clockwise loops and involutions occurred on both days. 
irregular (Fig. 5). Diurnal ranges of suspended-sediment transport were variable and values fluctuated by over $100 \%$ in only one or two hour periods. Greatest sediment-transport rates were associated with lower flows of the diurnal regimen of discharge.

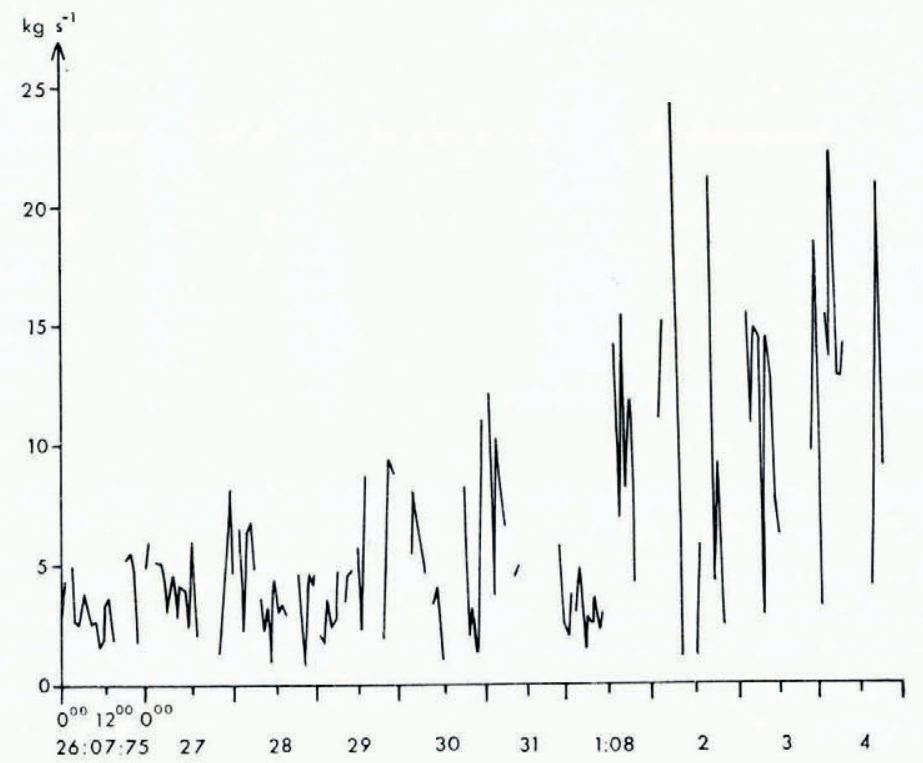

Fig. 5. Curve of suspended-sediment transport from 26 July to 4 August 1.975 with instantaneous suspended-sediment-transport measurements connected only for sequential hourly determinations. Extreme irregularity in suspended-sediment transport results from variations in sediment concentration.

\section{Discussion}

\section{Rapid temporal variations of suspended-sediment concentration}

Rapid erratic fluctuations of sediment concentration may result from samples unrepresentative of conditions in the Gornera at the time of collection. Occasional random inclusion of a few large sediment particles, which account for a large proportion of sample weight, may introduce apparent increases of sediment concentration not experienced in the stream. At higher discharges, when larger particles become suspended, sediment concentration may be overestimated by samples. Rudolph (1962) calculated centre-weighted averages from values adjacent to each data point to smooth temporal variations of sediment concentration, but data have not been filtered in this study. Similar rapid fluctuations in melt streams were observed by Mathews (1964) at Athabasca Glacier, Canadian Rocky Mountains, and by Østrem $\left(\left[{ }^{\mathrm{c}}{ }^{1} 975\right]\right)$ at Nigardsbreen, Norway.

Sudden large-magnitude variations of sediment concentration suggest subglacial instability beneath Gornergletscher. Random injection of sediment impulses may result from migration of basal streams during reorganization of subglacial drainage channels. Sediment impulses were often associated with the presence of large quantities of cobble-sized ice particles floating in the Gornera, suggesting that reorganization is of a sufficiently large scale to fracture large volumes of basal ice. During migration, channels impinge on unworked pockets of sediment stored at the ice-rock interface, providing ready but short-lived supplies of sediment load. Slumping from unstable morainic conduit margins may also produce sudden increases in sediment concentration followed by rapid exhaustion. 


\section{Subglacial sediment-transfer processes at Gornergletscher}

Temporal variations of the suspended-sediment concentration and transport, and concentration-discharge hysteresis relationships, suggest that the overall rate of sediment delivery to the subglacial hydrological system is variable on a diurnal basis and from day to day during the ablation season. Subglacial streams flowing in large arterial conduits probably incised into bedrock (Röthlisberger, I972) should transport all sediment supplied to them, and higher discharges of the diurnal regimen ensure sediment removal from major pipes of the hydrological network. Supply of sediment to the hydrological system from sites of production by erosion over wide areas of the glacier bed is probably achieved through smaller unstable conduits tributary to the arterial network.

Since basal moraine may consist of material incorporated in ice and as layers between ice and bedrock, relative movement of ice by sliding and channels by melting of their walls during expansion and migration provides sediments to the smaller subglacial streams by changing contact zones. The thick basal layer of sediments under Gornergletscher would provide a reservoir of sediment for supply to streams, and may be contributed by deformation into conduits, particularly at times of low water pressures, under the hydrostatic pressure of overlying ice. During highest diurnal discharges in late afternoon, the rate of sediment supply fails to maintain concentration in increasing volumes of flow, suggesting that increased shear stress at conduit margins is offset by increased volume-wetted perimeter ratios. Disproportionate increases in flow volumes in channels incised in bedrock over those in smaller conduits, or stable sedimentary margins to conduits, would account for decreased sediment concentrations at high discharges. However, low-flow sediment contributions and rapid variations of concentration point to conduit-margin instability, and suggest a flow-related reduction in the rate of sediment supply. Increased water pressure during high discharge may lessen the amount of deformation of basal sediments into conduits and some water may be forced into bank storage in basal moraine, to be returned later, during lower discharges, aiding collapse of conduit margins. Superimposed on this basic flow-related pattern, sudden conduit-course migrations, possibly initiated by blocking of conduits by sediments, integrate unworked zones of sediment with water flow.

\section{Subglacial processes during drainage of the Gornersee}

The rate of supply of sediment to subglacial streams increased throughout the emptying of the Gornersee. Enlarging conduit capacities during draining caused by melting of ice walls (Röthlisberger, I 972) would expose a decreasingly small area of sediments to possible entrainment relative to increasing discharge, causing sediment concentration in melt waters to peak and begin to decline before the time of maximum discharge. The large and sustained increase in sediment concentration throughout the rising flow of the lake burst suggests a major change in the subglacial drainage network, with the probable creation of many new channels beneath Gornergletscher. Continued expansion of the network over wider areas of the bed permitted continuing contact with zones of sediment throughout the drainage event.

\section{Conclusion}

Investigation of temporal variation in sediment concentration in melt waters and relationships with discharge provides a useful method of sampling subglacial conditions in the vicinity of conduits dispersed over large areas of a glacier bed, from which the nature of subglacial sediment-transfer processes and hydrological networks can be inferred. Although melt water has a significant role in sediment evacuation from the ice-bedrock interface at Gornergletscher, away from conduits, material not in transit in ice is accumulated in a thickness of subglacial 
moraine. Sediment concentration in melt waters depends on sediment supply and hydrological conditions. Most sediment is delivered to the smaller unstable conduits in the basal drainage network. Since it is unlikely that the rate of sediment production by erosion equals the rate of sediment transport by melt waters, expressed per unit area of glacier bed, accurate estimation of the rate of glacial erosion requires detailed close-interval samples of sediment concentration in melt waters over many annual cycles of discharge.

\section{AGKnowledgements}

The author gratefully acknowledges the following assistance: A. Bezinge and J. P. Perreten, Grande Dixence, S.A., for generous provision of field support and making available discharge records for the Gornera, and field assistance by members of the 1974 University of Liverpool and 1975 University of Manchester Gorner Glacier Expeditions.

\section{REFERENGES}

Benson, M. A. 1965. Spurious correlation in hydraulics and hydrology. Proceedings of the American Society of Civil Engineers. Fournal of the Hydraulics Division, Vol. 91, No. HY4, p. 35-42.

Bezinge, A., and others. 1973. Phénomènes du lac glaciaire du Gorner, par A. Bezinge, J. P. Perreten, et F. Schafer. Union Géodésique et Géophysique Internationale. Association Internationale d'Hydrologie Scientifique. Commission de Neiges et Glaces. Symposium on the Hydrology of Glaciers, Cambridge, 7-13 September 1969, p. 65-78. (Publication No. 95 de l'Association Internationale d'Hydrologie Scientifique.)

Church, M. 1972. Baffin Island sandurs: a study of Arctic fluvial processes. Canada. Geological Survey. Bulletin 2 r 6.

Liestøl, O. 1967. Storbreen glacier in Jotunheimen, Norway. Norsk Polarinstitutt. Skrifter, Nr. 141.

Mathews, W. H. 1964. Sediment transport from Athabasca Glacier, Alberta. [Union Géodésique et Géophysique Internationale. Association Internationale d'Hydrologie Scientifique.] Assemblée générale de Berkeley de l'UGGI, I9-8-3I-8 1963. Erosion continentale, précipitations, hydrométrie, humidité du sol, p. ${ }_{5} 5_{5}^{-6}$. (Publication No. 65 de l'Association Internationale d'Hydrologie Scientifique.)

Østrem, G. [ [ ${ }^{1}{ }_{1975 .]}$ Sediment transport in glacial meltwater streams. (In Jopling, A. V., and McDonald, B. C., ed. Glaciofluvial and glaciolacustrine sedimentation. Tulsa, Oklahoma, Society of Economic Paleontologists and Mineralogists, p. Ior-22. (Special Publication No. 23.))

Østrem, G., and others. 1967. Glacio-hydrology, discharge, and sediment transport in the Decade Glacier area, Baffin Island, N.W.T., by G. Østrem, C. W. Bridge, and W. F. Rannie. Geografiska Annaler, Vol. 49A, Nos. 3-4, p. 268-82.

Reynolds, R. C., and Johnson, N. M. 1972. Chemical weathering in the temperate glacial environment of the Northern Cascade Mountains. Geochimica et Cosmochimica Acta, Vol. 36, No. 5, p. 537-54.

Röthlisberger, H. 1972. Water pressure in intra- and subglacial channels. Fournal of Glaciology, Vol. I I, No. 62, p. $177-203$.

Rudolph, R. 1962. Abflussstudien an Gletscherbächen. Methoden und Ergebnisse hydrologischer Untersuchungen in den zentralen Ötztaler Alpen in den Jahren 1953-1955. Veröffentlichungen des Museum Ferdinandeum in Innsbruck, Bd. 41, Jahrg. 1961, p. 11 7-266.

Vivian, R. A., and Zumstein, J. 1973. Hydrologie sous-glaciaire au glacier d'Argentière (Mont-Blanc, France). Union Géodésique et Géophysique Internationale. Association Internationale d'Hydrologie Scientifique. Commission de Neiges et Glaces. Symposium on the Hydrology of Glaciers, Cambridge, 7-13 September 1969, p. 53-64. (Publication No. 95 de l'Association Internationale d'Hydrologie Scientifique.)

Walling, D. E. r977. Assessing the accuracy of suspended sediment rating curves for a small basin. Water Resources Research, Vol. 13, No. 3, p. $53^{1-38 .}$

\section{DISGUSSION}

G. S. Boulton: Why do you say that stream discharge cannot yield an estimate of glacial erosion rates provided that long-term averages are taken? It seems unlikely in most cases that net increase in storage of subglacial sediments or net loss of pre-existing sediments would produce large errors.

D. N. Collins: While the addition of sediment to subglacial storage depends on erosion conditions at the ice-sediment-rock interface, and occurs over large areas of the glacier bed, evacuation of sediment in melt-water streams depends on the interaction of temporally 
varied and spatially restricted hydrological conditions. Subglacial channels may migrate across the bed but the length of time necessary for access of waters to all areas of the bed will be great. Observations over short periods (even if intensive close-interval sampling is undertaken) will be unrepresentative of average conditions, since a large proportion of total annual sediment transport can occur in a period of 1 or $2 \mathrm{~d}$, which may or may not be in the observation period. Great variation in transport between years suggests also that rate of supply and rate of removal of sediment from storage are not equal over two- or three-year periods. 